\title{
Frozen-Ground Cartoons
}

\section{Permafrost comics as an innovative tool for polar outreach, education, and} engagement

Bouchard, Frédéric; Sansoulet, Julie; Fritz, Michael; Malenfant-Lepage, Julie; Nieuwendam, Alexandre; Paquette, Michel; Rudy, Ashley C.A.; Siewert, Matthias B.; Sjöberg, Ylva; Tanski, George; Habeck, J. Otto; Harbor, Jon

\section{Published in: \\ Polar Record}

DOI:

$10.1017 / \mathrm{S} 0032247418000633$

Publication date:

2019

Document version

Peer reviewed version

Citation for published version (APA):

Bouchard, F., Sansoulet, J., Fritz, M., Malenfant-Lepage, J., Nieuwendam, A., Paquette, M., Rudy, A. C. A., Siewert, M. B., Sjöberg, Y., Tanski, G., Habeck, J. O., \& Harbor, J. (2019). Frozen-Ground Cartoons: Permafrost comics as an innovative tool for polar outreach, education, and engagement. Polar Record, 54(5-6), 366-372. https://doi.org/10.1017/S0032247418000633 
"Frozen-Ground Cartoons": Permafrost comics as an innovative tool for polar outreach, education, and engagement

\begin{tabular}{|r|l|}
\hline Journal: & Polar Record \\
\hline Manuscript ID & POL-RN-2018-0007.R2 \\
\hline Manuscript Type: & Research Note \\
\hline Keywords: & Permafrost, Polar education, Scientific outreach, Comic strips, Cartoons \\
\hline
\end{tabular}

\section{SCHOLARONE Manuscripts}




\section{"Frozen-Ground Cartoons": Permafrost}

2 comics as an innovative tool for polar

3 outreach, education, and engagement

5 Frédéric Bouchard ${ }^{1,2}$, Julie Sansoulet ${ }^{2,3}$, Michael Fritz ${ }^{4}$, Julie Malenfant-Lepage ${ }^{2,5}$, Alexandre

6 Nieuwendam ${ }^{6}$, Michel Paquette $^{7}$, Ashley C. A. Rudy ${ }^{8}$, Matthias B. Siewert ${ }^{9}$, Ylva Sjöberg $^{10}$,

7 George Tanski ${ }^{4,11}$, Joachim Otto Habeck ${ }^{12}$, Jon Harbor ${ }^{13}$

8

91 Université Paris Saclay, Orsay, France

102 Université Laval, Québec, Canada

$11{ }^{3}$ CNRS, Paris, France

$12{ }^{4}$ Alfred Wegener Institute, Potsdam, Germany

$13{ }^{5}$ Norwegian University of Science and Technology, Trondheim, Norway

$14{ }^{6}$ Centre of Geographical Studies - IGOT, Universidade de Lisboa, Portugal

$15 \quad{ }^{7}$ Queen's University, Kingston, Canada

$16 \quad{ }^{8}$ Wilfrid Laurier University, Waterloo, Canada

179 Umeå University, Umeå, Sweden

$18{ }^{10}$ Stockholm University, Stockholm, Sweden

$19{ }^{11}$ Vrije Universiteit Amsterdam, Amsterdam, The Netherlands

$20 \quad{ }^{12}$ Universität Hamburg, Hamburg, Germany

$21{ }^{13}$ Purdue University, West Lafayette, USA 


\section{Abstract}

24 Permafrost occupies 20 million square kilometres of Earth's high-latitude and high-altitude 25 landscapes. These regions are sensitive to climate change and human activities; hence, 26 permafrost research is of considerable scientific and societal importance. However, the results 27 of this research are generally not known by the general public. Communicating scientific 28 concepts is an increasingly important task in the research world. Different ways to engage 29 learners and incorporate narratives in teaching materials exist, yet they are generally 30 underused. Here we report on an international scientific outreach project called "Frozen31 Ground Cartoons", which aims at making permafrost science accessible and fun for students, 32 teachers, and parents through the creation of comic strips. We present the context in which 33 the project was initiated, and recent education and outreach activities. The future phases of 34 the project primarily involve a series of augmented reality materials, such as maps, photos, 35 videos, and 3D drawings. With this project we aim to foster understanding of permafrost 36 research among broader audiences, inspire future permafrost researchers, and raise public 37 and science community awareness of polar science, education, outreach, and engagement. 38 


\section{Introduction}

41 "Science is not a heartless pursuit of objective information. It is a creative human activity, its 42 geniuses acting more as artists than as information processors." (Gould, 1979, p. 201) 43

44 Occupying more than 20 million square kilometres (Fig. 1), permafrost is a key landscape 45 component of high-latitude and high-altitude regions (Brown et al., 1998). Ongoing climate warming, which is especially acute in the circumpolar North, results in a series of profound environmental impacts including permafrost thaw and erosion (AMAP, 2017; IPCC, 2013).

This in turn can release organic carbon formerly trapped in frozen soils to the atmosphere, ultimately enhancing global warming (Schuur et al., 2015). Considering that twice as much carbon is currently stored in permafrost compared to the atmosphere (Hugelius et al., 2014), frozen-ground landscapes play a key role in global climate and large-scale biogeochemical cycles.

Across the Arctic, about four million people live in permafrost areas, particularly in Alaska, Canada, Russia, and Greenland. Frozen-ground landscapes have been used in the past by various indigenous peoples for settlement and hunting-fishing grounds, resulting in extensive 'traditional environmental knowledge' about these ecosystems. This knowledge provides valuable resources for science and community planning (Tondu et al., 2014; Calmels et al., 2015). Still, construction and maintenance of infrastructure in permafrost regions is difficult, and is further exacerbated by climate change impacts and an urgent need for housing (Melvin et al., 2016). Hence, permafrost dynamics and interactions with local infrastructure and communities are of key scientific interest (Fritz et al., 2015).

64 In this context, science communication to stakeholders and the general public is increasingly important. Several education and outreach initiatives stemming from the International Polar 66 Year (IPY, 2007-2008) have been proposed in various formats, including field courses, 
67 exchanges with educators and support for early career networks (e.g., Christiansen et al., 68 2007; Beck et al., 2014; Provencher et al., 2011). Among them, the Permafrost Young 69 Researchers Network (PYRN) and the Association of Polar Early Career Scientists (APECS) 70 foster innovative collaborations among the younger generations and within the whole polar 71 research community (Tanski et al., this special issue). The IPY $10^{\text {th }}$ anniversary invites 72 reflection on past accomplishments and future perspectives on polar research education and 73 outreach.

74 75

This Research Note reports on an innovative, multidisciplinary, and international education/outreach initiative called "Frozen-Ground Cartoons". First, we present the initial 77 cartoons, which are a series of illustrated stories related to permafrost research with a focus 78 on fieldwork activities and interactions with local communities. We then discuss ongoing and future outcomes stemming from the cartoons, as well as dissemination strategies.

\section{A collaboration between artists and permafrost}

\section{2 scientists}

Science education and communication can take many forms, ranging from traditional classroom lectures, or images visible in Google Earth (Ballagh et al., 2007), to more unusual initiatives such as the use of poetry in chemistry classes (Araújo et al., 2015), or analysis of

'The Simpsons' in physics curriculum (Perales-Palacios \& Vilchez-Gonzalez, 2005). Comic strips or cartoons (the terms are often used interchangeably) can serve as powerful science communication tools: they are visual, generally funny, depict scientific concepts from a different perspective, and can be easily transferred between different language formats and shared via social media (e.g., Dominiczak, 2017; Mignone et al., 2016; Shurkin, 2015). 
92

93

94

\section{Background}

Finding artists

more broadly, they help communicate science to the public and get the reader engaged, an important task of any scientific activity (Farinella, 2018; Tatalovic, 2009).

The establishment of early-career researcher (ECR) networks was an important component of education, outreach and communication initiatives during IPY (Krupnik et al., 2011). This culminated in the establishment of APECS and PYRN in 2005 (Baeseman et al., 2011; Tanski et al., this special issue), which now reach out to as many as 5000 and 1200 members, respectively. Also emerging from the IPY legacy were two major research programs dedicated to permafrost research: the pan-Canadian program, Arctic Development and Adaptation to Permafrost in Transition (ADAPT), and the pan-European program, Changing Permafrost in the Arctic and its Global Effects in the 21st Century (PAGE21). These interdisciplinary research programs provided organizational and financial support for a network of ECRs who actively engaged with APECS and PYRN. This collaboration resulted in a publication outlining the future directions of permafrost science from the perspective of ECRs (Fritz et al., 2015).

\section{The "Frozen-Ground Cartoons" (FGC) project}

The FGC project was initiated in 2015 by a core group stemming from the ECR collaboration (Fritz et al., 2015), and its aim was to develop a series of informative comics for school kids and teachers. The comics address important concepts about permafrost (e.g., distribution and dynamics of frozen ground, including human impacts, fieldwork activities) and were intended to be used for education and outreach of permafrost science worldwide, therefore contributing to the recruitment of the next generation of permafrost scientists. 
117 The project was officially launched as a two-year 'Action Group' funded by the International

118 Permafrost Association (IPA). An application call for illustrators was sent through a number of

119 national and international networks as well as through email lists related to art and science

120 communication. A total of 49 applications were received from 16 different countries (Fig. 2).

121 Following an evaluation process (Fig. S1), 10 applicants were selected to submit a one-page

122 cartoon 'pitch'. Applicants were provided with material specific to permafrost research (e.g.,

123 fieldwork pictures, sketches, non-specialist texts). After a second round of evaluation, two

124 artists were selected based on overall quality and potential to reach a large audience: Heta

125 Nääs from Helsinki (Finland), and Noémie Ross from Montréal (Canada).

126

127 Developing stories

128 The following year was spent developing different scenarios and characters, an iterative process involving both the artists and the scientists via several online meetings and a one-day workshop. With topics suggested by the science group, the artists were ultimately given complete freedom to interpret the content and draft stories and characters (Fig. 3). After

132 completion of the first drafts of the comics, the science group provided feedback to the artists, 133 and edits were made until everybody agreed on final versions. A one-minute video trailer of 134 the project, titled 'FrostByte', was released in late 2017 135 (https://frozengroundcartoon.com/2017/12/08/frozen-ground-cartoon-frost-byte/).

137 Translations and science outreach

138 Final English versions of the FGC were completed in 2017 and culminated in a 28-page printed 139 booklet containing all the cartoons, as well as a foreword and an illustrated permafrost 140 glossary (Nääs et al., 2017) (Fig. 4). The booklet has been published under a creative 141 commons license (CC) including an ISBN number and a permanent doi. Meanwhile, a 142 Swedish version was produced and printed for the Bolin Centre Climate Festival held in 143 Stockholm in May 2017 (Fig. 5). The Swedish version included translations of the comics, as 144 well as back covers that presented illustrations of permafrost distribution and reindeer herding 
145 in Scandinavia. The French version was released in October 2018 as a feature event of the 146 'Fête de la Science', held across France.

148 Currently, cartoons are being translated into Russian and German, the focus in 2019 being on 149 languages spoken in permafrost regions or by stakeholders in permafrost science (e.g. 150 Inuktitut, Komi, Yakutian, Korean, Japanese, Chinese). Particular attention will be put to the 151 translation into indigenous languages, which are rarely represented in specialized and 152 mainstream media. This will give native speaker groups access to the scientific narratives on 153 permafrost and environmental research in their own language and further enable and 154 empower them to take part in local, regional and global dialogues about permafrost 155 degradation impacts across the Arctic.

157 Other ongoing and future outcomes

158 Augmented Reality (AR) material

159 We are in the process of complementing our cartoons with AR material during the next years. 160 We will produce maps, photos, videos, and 3D drawings that will be readily available via an 161 application developed for smartphones and tablets (Fig. 6). Maps will allow the user to 162 dynamically visualize in 3D and understand (i) permafrost distribution around the world, (ii) 163 climate warming amplification in the Arctic, and (iii) erosion processes in permafrost areas and 164 their consequences for the environment and the local population. Secondly, we will use 165 numerous fieldwork photos gathered by scientists through the years, and 3D drawings 166 developed from these photos, to highlight permafrost properties (Fig. 7). We will also present 167 tools and equipment used for permafrost research, typical ecosystems or wildlife species, and 168 how house construction is adapted to the Arctic. Finally, educational videos will provide 169 information about (i) permafrost physical properties, (ii) fieldwork campaigns ${ }^{1}$, (iii) sample

\footnotetext{
${ }^{1} \mathrm{https}: / /$ www.youtube.com/watch?v=2zKSZRHIzQU
} 
170 collecting and analyzing in the field and in the laboratory, (iv) climate change impacts and 171 mitigation strategies, and $(v)$ inputs on how scientists collaborate with local communities to 172 co-produce knowledge. This will provide an innovative way of presenting permafrost science 173 to a wide range of diverse user groups.

174

175 Board game

176 The objective of this initiative is to build a high-quality science-themed game, associated with 177 the AR material, where permafrost science itself drives the gameplay. We will use a 178 multiplayer permafrost world map platform (Fig. 1) to engage the whole family or the whole 179 classroom in educative travel. Questions will be split into six categories: geography, physics, 180 chemistry, biology, social sciences, and history. Players will test their knowledge, visualizing 181 AR tools at each step of the game. As young permafrost scientists, they will innovate, test 182 hypotheses, publish articles, and collaborate with stakeholders or with other scientists.

\section{Dissemination and plans for formal evaluation}

185 Innovation of new technologies has led to the development of new approaches to encourage 186 dialogue between scientists and the general public and students, while also inspiring people 187 to take an active role in science. The goal of the FGC project was to develop an outreach tool 188 to effectively engage with a number of audiences, such as targeted students, schools, 189 discipline-specific networks, professional bodies, and educational communities. With this aim, 190 the project combines traditional and innovative ways of communicating knowledge about 191 permafrost.

193 First, the cartoons were presented in schools. The Swedish version of the comics was printed 194 for distribution to school children in the Stockholm area. The cartoons were also presented 195 and distributed to high school students and teachers in a scientific activity in connection with 
196 the Arctic Frontiers Conference in Tromsø (Norway). With these school activities, we have 197 initiated an informal evaluation of the comics, which focuses on the inspirational aspects (Are 198 the comics liked? Are they fun and inspiring?), the learning outcomes (What do the children 199 learn from reading the comics?), and the teaching aspects (Are the teachers helped in their 200 work by the comics?). The evaluation is performed through a short quiz as well as by a drawing 201 exercise named "Design the ultimate permafrost-meter!" (Fig. S2). The results will help in 202 planning new comic-based outreach material, as well as how to best use the comics in 203 outreach and education efforts as part of a formal evaluation process. 204 205 As a second step, we actively involved different target groups through the development of a 206 website: https://frozengroundcartoon.com/. Since its launch in July 2017, we have recorded 207 over 11,700 views from 3730 people from 87 countries (by 17 December 2018). The majority 208 of the visitors were from countries with strong permafrost research programs, such as Canada, 209 United States, Germany, Russia, and Scandinavian countries. However, there have also been 210 visitors from less expected countries such as Saudi Arabia, Malaysia, Cyprus, and Peru. 211 Scientists interested in the project can get updates on the project via the project blog on 212 Researchgate ${ }^{2}$ or on the main website.

213

214 To inform and encourage permafrost scientists to use these resources, the project was 215 presented at scientific conferences. In late 2017, the first copies of the booklet were distributed 216 at the American Geophysical Union Fall Meeting (Sjöberg et al., 2017) and at the International 217 Arctic Change 2017 Conference (Paquette et al., 2017). During the IPA Action Group period, 218 spanning two years between January 2016 and January 2018, a total of 10 presentations were 219 made at a range of scientific and general public events (Table S1).

\footnotetext{
${ }^{2}$ https://www.researchgate.net/project/A-Frozen-Ground-Cartoon-Explaining-international-permafrostresearch-using-comic-strips
} 


\section{Conclusions}

222 Teaching and communicating science to the public, especially to school children, can 223 sometimes be a daunting task. Cartoons can be used to extract essential information on 224 complex environmental and social issues and tell stories that capture readers' interest, 225 including groups that are underserved by other channels of science communication. Polar 226 science, including permafrost science, lends itself well to this kind of outreach activity (e.g., 227 fieldwork in remote areas, spectacular landscapes, fossilized mammoth bones, cultural 228 heritage of Arctic communities).

230 From the very beginning, Frozen-Ground Cartoons were meant to provide permafrost science 231 concepts and materials in a casual, popular, and efficient way. Based on the comments 232 received so far from scientists, teachers, and the general public including children, the project 233 seems to be moving in the right direction. Yet, there are still a lot of opportunities to extend 234 this work and we provide future ideas and directions to bring our science to new audiences. 235 Augmented reality material is gaining popularity and relevance in the science curriculum as 236 well as in education and public outreach activities, and we are adapting this new reality to 237 permafrost science communication. Combined with the proposed board game for families and 238 classrooms, there is truly an opportunity to take this outreach project to another level. Besides 239 funding, the only limit for future developments seems to be our imagination.

\section{Acknowledgements}

242 We sincerely thank the artists, Heta Nääs and Noémie Ross, for creating engaging permafrost 243 stories and characters. We are also grateful to Bethany Deshpande, Audrey Veillette and 244 Stefanie Weege for participating in the production of the scientific material shown in the 245 booklet, and to Warwick F. Vincent for reviewing early drafts of the cartoons. Financial support 
246 was provided for artist compensation and material printing by the International Permafrost 247 Association (IPA), the International Arctic Science Committee (IASC), Climate and 248 Cryosphere (CliC), Arctic Development and Adaptation to Permafrost in Transition (ADAPT), 249 the Permafrost Young Researchers Network (PYRN), the Bolin Centre for Climate Research, 250 the Alfred Wegener Institute Helmholtz Centre for Polar and Marine Research (AWI), the 251 Association of Polar Early Career Scientists (APECS), and the IMPACT! Fund. Upcoming 252 production of augmented reality material is funded by IASC and the H2020 project Nunataryuk 253 under grant agreement No. 773421. 254 255 


\section{References}

257 AMAP, 2017. Snow, Water, Ice and Permafrost in the Arctic (SWIPA) 2017. Olso: Arctic

258 Monitoring and Assessment Programme (AMAP).

259

260 Araújo, J. L., Morais, C., Paiva, J. C. (2015). Poetry and alkali metals: Building bridges to the 261 study of atomic radius and ionization energy. Chemistry Education Research and Practice, 262 16(4), 893-900. doi: 10.1039/c5rp00115c.

263

264 Ballagh, L. M., Parsons, M. A., Swick, R. (2007). Visualising cryospheric images in a virtual 265 environment: Present challenges and future implications. Polar Record, 43, 305-310. doi: 266 10.1017/S0032247407006523. 267 268

Baeseman, J., Xavier, J., Lantuit, H., Taylor, A. (2011). Early Career Researchers Activities 270 during IPY. In: Krupnik, I., Allison, I., Bell, R., Cutler, P., Hik, D., López-Martínez, J., Rachold, V., Sarukhanian, E., Summerhayes, C. (eds.). Understanding Earth's Polar 271 Challenges: International Polar Year 2007-2008. Summary by the IPY Joint Committee. 272 Rovaniemi: University of the Arctic and ICSU/WMO Joint Committee for International Polar 273 Year 2007-2008.

274

275 Beck, I., Huffman, L. T., Xavier, J. C. C., Walton, D. W. H. (2014). Education and Polar 276 Research: Bringing Polar Science into the Classroom. Journal of Geological Resource and 277 Engineering, 4, 217-221. doi:10.17265/2328-2193/2014.04.004.

278

279 Brown, J., Ferrians, O. J., Heginbottom, J. A., Melnikov, E.S. (1998). Circum-Arctic map of 280 permafrost and ground-ice conditions. Boulder: National Snow and Ice Data Center/World 281 Data Center for Glaciology (revised February 2001). 
283 Calmels, F., Laurent, C., Brown, R., Pivot, F., Ireland, M. (2015). How Permafrost Thaw May 284 Impact Food Security of Jean-Marie River First Nation, NWT. Proceedings of the $7^{\text {th }}$ 285 Canadian Permafrost Conference and the $68^{\text {th }}$ Canadian Geotechnical Conference, Quebec 286 (Canada), September 2015. 287

288 Christiansen, H. H., Prick, A., Lantuit, H. (2007). Report from the International Permafrost 289 Association: Education and outreach for the International Polar Year. Permafrost and 290 Periglacial Processes, 18, 209-213. doi: 10.1002/ppp.590.

291

292 Dominiczak, M. H. (2017). Cartoons: another long-standing bridge between science and the 293 arts. Clinical Chemistry, 63(4), 934-935. doi: 10.1373/clinchem.2016.266783. 294 295 Farinella, M. (2018). The potential of comics in science communication. Journal of Science 296 Communication, 17(01), Y01. doi: 10.22323/2.17010401.

297

298 Fritz, M., Deshpande, B. N., Bouchard, F., Högström, E., Malenfant-Lepage, J., 299 Morgenstern, A., ... Weege, S. (2015). Brief Communication: Future avenues for permafrost 300 science from the perspective of early career researchers. The Cryosphere, 9, 1715-1720. 301 doi: 10.5194/tc-9-1715-2015.

302

303 Gould, S. J. (1979). Ever Since Darwin: Reflections in Natural History. New York: Norton, $304285 \mathrm{p}$. 305 306 Hugelius, G., Strauss, J., Zubrzycki, S., Harden, J. W., Schuur, E. A. G., Ping, C. L., ... 307 Kuhry, P. (2014). Estimated stocks of circumpolar permafrost carbon with quantified 308 uncertainty ranges and identified data gaps. Biogeosciences, 11, 6573-6593. doi: $309 \quad 10.5194 / \mathrm{bg}-11-6573-2014$. 310 
311 IPCC (2013). Climate Change 2013: The Physical Science Basis. Contribution of Working

312 Group I to the Fifth Assessment Report of the Intergovernmental Panel on Climate Change.

313 Cambridge (UK) and New York (USA): Cambridge University Press.

314

315 Krupnik, I., Allison, I., Bell, R., Cutler, P., Hik, D., López-Martínez, J., ... Summerhayes, C.

316 (eds.) (2011). Understanding Earth's Polar Challenges: International Polar Year 2007-2008.

317 Summary by the IPY Joint Committee. Rovaniemi: University of the Arctic and ICSU/WMO

318 Joint Committee for International Polar Year 2007-2008.

319

320

Melvin, A. M., Larsen, P., Boehlert, B., Neumann, J. E., Chinowsky, P., Espinet, X., ...

321

Marchenko, S. S. (2016). Climate Change Damages to Alaska Public Infrastructure and the

322

Economics of Proactive Adaptation. Proceeding of the National Academy of Sciences: E122-

323

131. doi:10.1073/pnas.1611056113.

324

325

Mignone, C., Homfeld, A. M., Marcu, S., Baldwin, E., Bauer, M., Palazzari, C., ...

McCaughrean, M. (2016). How a cartoon series helped the public care about Rosetta and

Philae. CAP (Communicating Astronomy with the Public) Journal, 19, 12-18.

328

329

Nääs, H., Ross, N., Bouchard, F., Deshpande, B., Fritz, M., Malenfant-Lepage, J., ..

Habeck, J. O. (2017). Frozen-Ground Cartoons: An international collaboration between

artists and permafrost scientists. Potsdam: Bibliothek Wissenschaftspark Albert Einstein, 27

332

p. doi: 10.2312/GFZ.LIS.2017.001.

333

334

Paquette, M., Bouchard, F., Deshpande, B. N., Fritz, M., Malenfant-Lepage, J.,

335

Nieuwendam, ... Weege, S. (2017). Permafrost Comics: Bridging the gap between science

336

and society. International Arctic Change Conference 2017, Québec, Canada, 11-15

337 December.

338 
339 Perales-Palacios, F. J., Vílchez-González, J. M. (2005). The teaching of physics and 340 cartoons: Can they be interrelated in secondary education? International Journal of Science 341 Education, 27(14), 1647-1670. doi: 10.1080/09500690500206366.

342

343 Provencher, J., Baeseman, J., Carlson, D., Badhe, R., Bellman, J., Hik, D., ... Zicus, S.

344 (2011). Polar Research Education, Outreach and Communication during the fourth IPY: How 345 the 2007-2008 International Polar Year has contributed to the future of education, outreach 346 and communication. Paris: International Council for Science (ICSU).

347 https://munin.uit.no/bitstream/handle/10037/3730/article.pdf?sequence=1 348

349 Schuur, E. A. G., Mcguire, A. D., Schadel, C., Grosse, G., Harden, J. W., Hayes, D. J., ... 350 Vonk, J. E. (2015). Climate change and the permafrost carbon feedback. Nature, 520, 171351 179. doi: 10.1038/nature14338.

352

353 Shurkin, J. (2015). Science and Culture: Cartoons to better communicate science.

354 Proceedings of the National Academy of Sciences of the United States of America (PNAS), 355 112(38), 11741-11742. doi: 10.1073/pnas.1515144112. 356

357 Sjöberg, Y., Bouchard, F., Deshpande, B. N., Fritz, M., Malenfant-Lepage, J., 358 Nieuwendam, A., ... Harbor, J. (2017). Frozen-Ground Cartoons: An international 359 collaboration between artists and permafrost scientists. American Geophysical Union (AGU) 360 Fall Meeting 2017, New Orleans, USA, 11-15 December. 361

362 Tanski, G., Bergstedt, H., Bevington, A., Bonnaventure, P., Bouchard, F., Coch, C., ... 363 Lantuit, H. (in review). The Permafrost Young Researchers Network (PYRN) is getting older 364 - the past, present, and future of our evolving community. Polar Record, special issue on 365 education, outreach, and engagement ("10 years of Polar Education, Outreach and 366 Communication initiatives"). 
368 Tatalovic, M. (2009). Science comics as tools for science education and communication: a

369 brief, exploratory study. Journal of Science Communication, 8(4), A02. doi:

$370 \quad 10.22323 / 2.08040202$.

371

372 Tondu, J. M. E., Balasubramaniam, A. M., Chavarie, L., Gantner, N., Knopp, J. A.,

373 Provencher, J. F., ... Simmons, D. (2014). Working with Northern Communities to Build

374 Collaborative Research Partnerships: Perspectives from Early Career Researchers. Arctic, 375 67, 419-429, 2014. doi: 10.14430/arctic4416.

376 


\section{Figure captions}

378 Figure 1. Permafrost distribution map in the Northern Hemisphere (Brown et al., 1998).

379

380 Figure 2. Provenance (country or territory of residence) of the applications received $(n=49)$

381 during Winter 2016 (https://frozengroundcartoon.com/the-process/).

382

383 Figure 3. Preliminary sketches in 2016. Left: preliminary character bios shown as a mind 384 map. Right: preliminary ideas for one specific character. Drawing credit: Heta Nääs. 385

386 Figure 4. Sample of the illustrated permafrost glossary (Nääs et al., 2017). 387

388 Figure 5. Sample of the Swedish version, produced for the Bolin Centre Climate Festival 389 held in Stockholm in May 2017. Drawing credit: Heta Nääs.

390

391 Figure 6. Examples of augmented reality materials that can be developed based on different 392 products. Above: from a science school book. Below: from a card game about 393 phytoplankton. Pictures: courtesy of J. Sansoulet. 394

395 Figure 7. Examples of sketches that could be used to develop AR material. Left: permafrost 396 distribution varying with latitude (source: @Science-Art.com). Right: permafrost and ground 397 ice illustrated with 3ds Max and Photoshop (source: @Vladimir Andreev). 


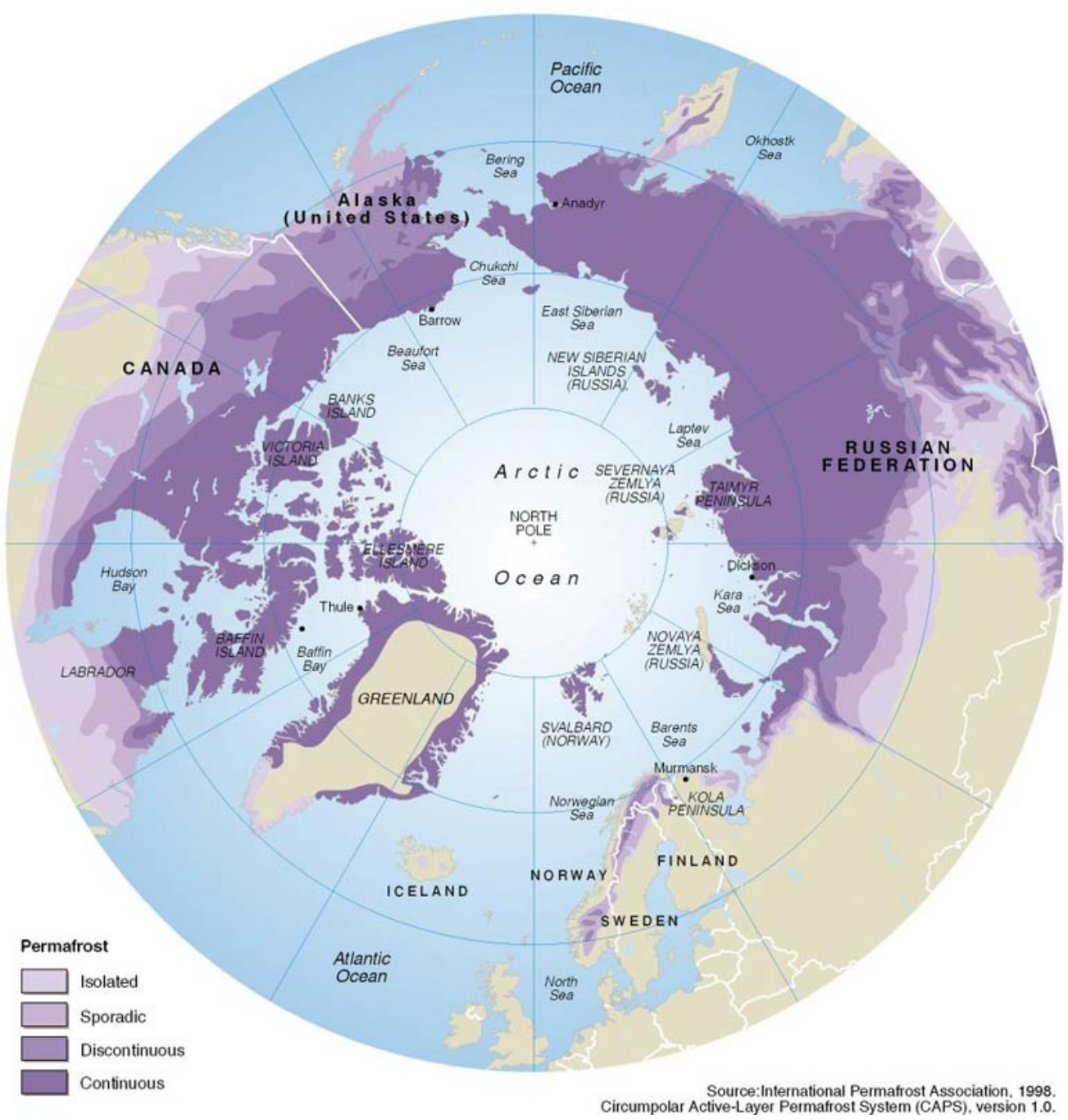

Figure 1. Permafrost distribution map in the Northern Hemisphere (Brown et al., 1998).

$196 \times 203 \mathrm{~mm}(100 \times 100 \mathrm{DPI})$ 


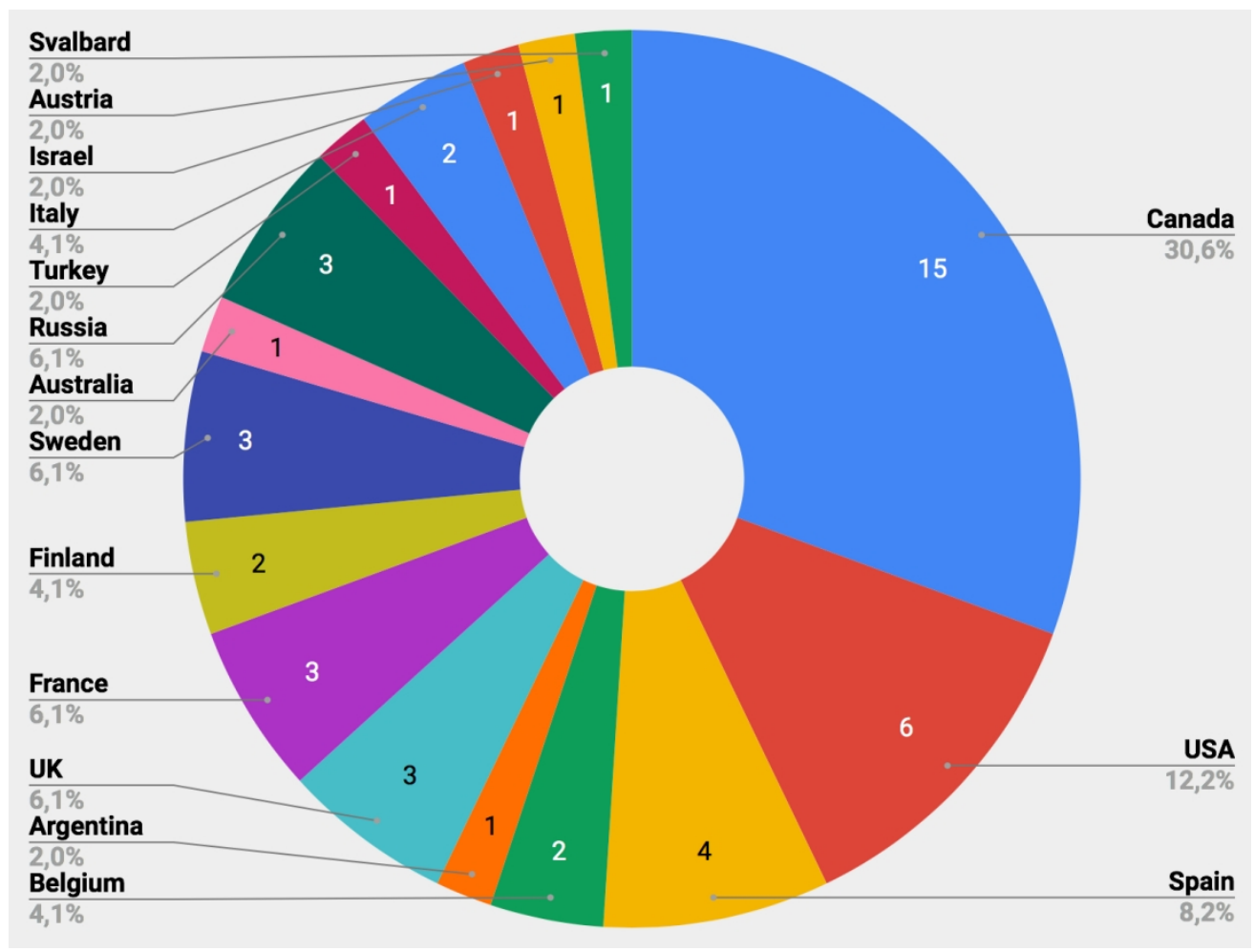

Figure 2. Provenance (country or territory of residence) of the applications received $(n=49)$ during Winter 2016 (https://frozengroundcartoon.com/the-process/).

$269 \times 203 \mathrm{~mm}(144 \times 144 \mathrm{DPI})$ 

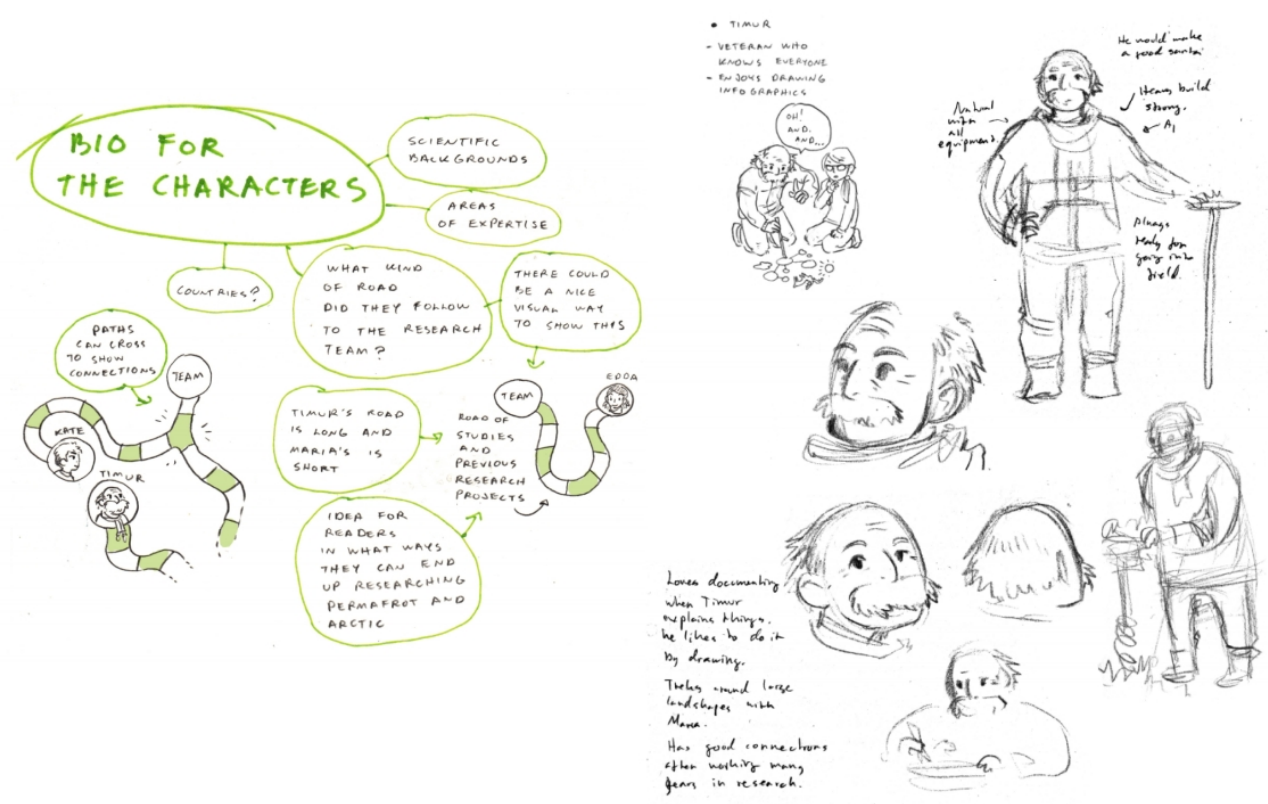

Figure 3. Preliminary sketches in 2016. Left: preliminary character bios shown as a mind map. Right: preliminary ideas for one specific character. Drawing credit: Heta Nääs.

\section{$205 \times 129 \mathrm{~mm}(300 \times 300$ DPI $)$}




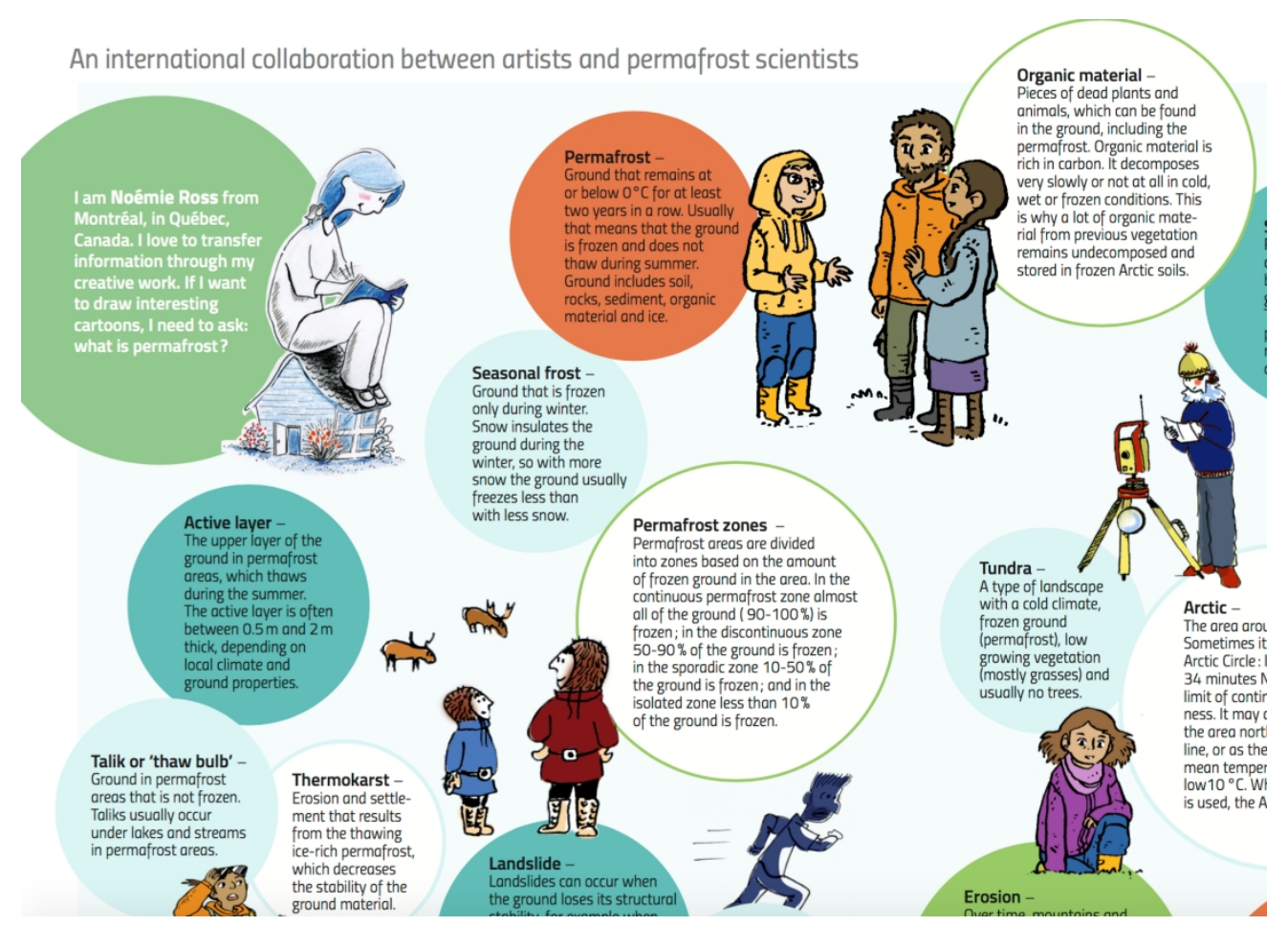

Figure 4. Sample of the illustrated permafrost glossary (Nääs et al., 2017).

$357 \times 257 \mathrm{~mm}(144 \times 144$ DPI $)$ 


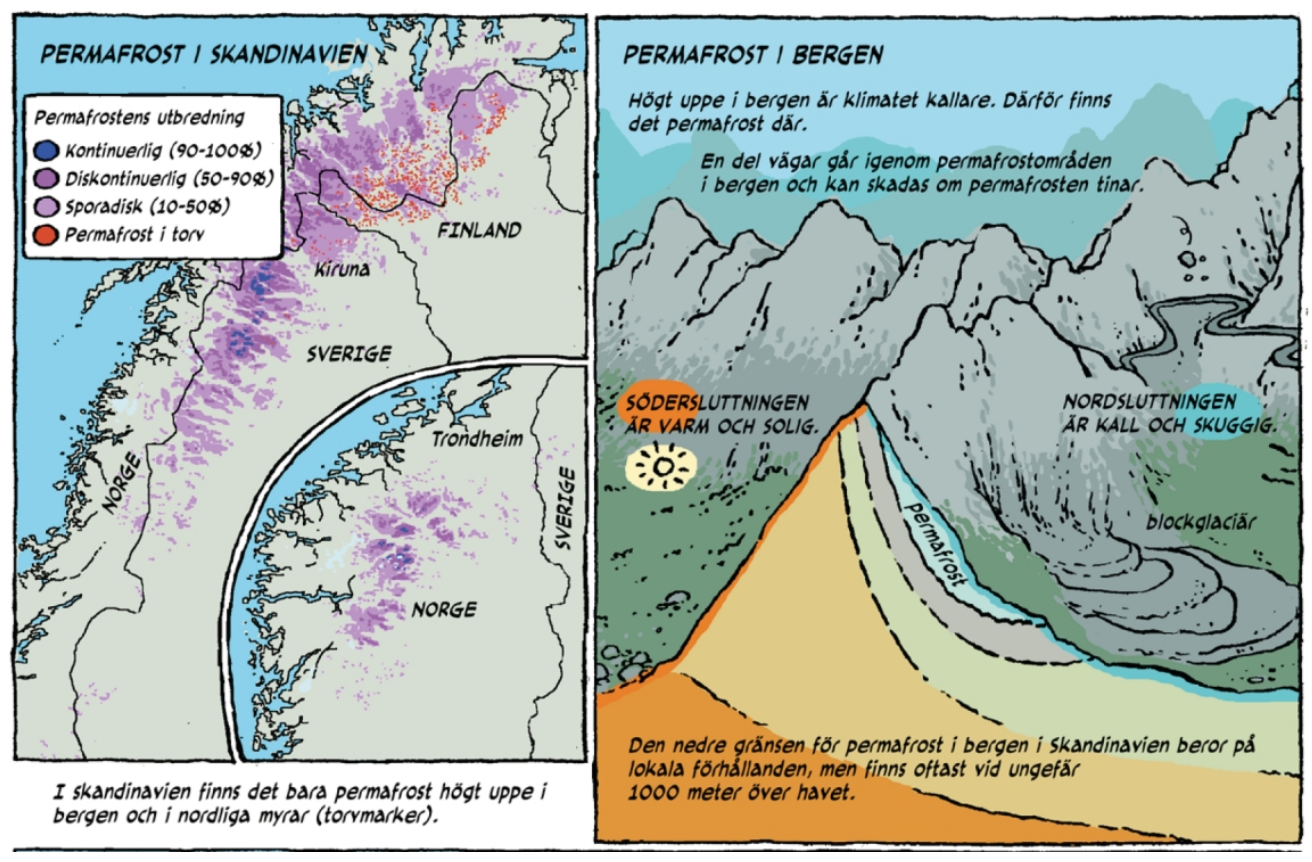

Figure 5. Sample of the Swedish version, produced for the Bolin Centre Climate Festival held in Stockholm in May 2017. Drawing credit: Heta Nääs.

$$
314 \times 205 \mathrm{~mm} \text { (144 x } 144 \text { DPI) }
$$


Figure 6. Examples of augmented reality materials that can be developed based on different products. Above: from a science school book. Below: from a card game about phytoplankton. Pictures: courtesy of J. Sansoulet. 

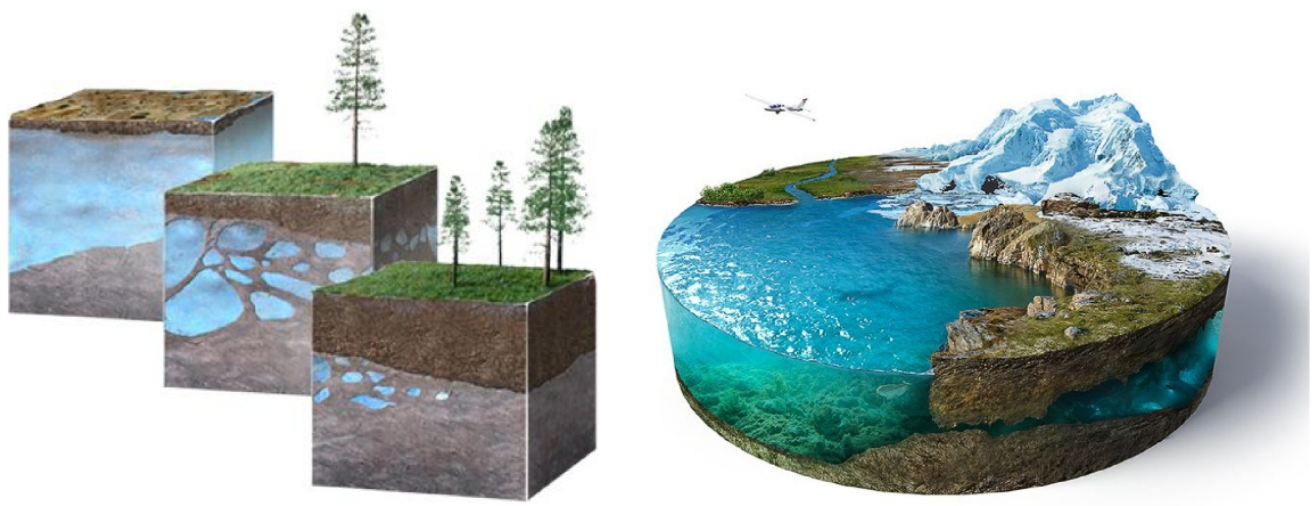

Figure 7. Examples of sketches that could be used to develop AR material. Left: permafrost distribution varying with latitude (source: @Science-Art.com). Right: permafrost and ground ice illustrated with 3ds Max and Photoshop (source: @Vladimir Andreev). 